\title{
Correction to: Mid-spatial frequency error generation mechanisms and prevention strategies for the grinding process
}

Mario Pohl ${ }^{1 *}$, Olga Kukso ${ }^{2}$, Rainer Boerret ${ }^{1}$ and Rolf Rascher $^{2}$

Correction to: J. Eur. Opt. Soc.-Rapid Publ. 16, 19 (2020)

https://doi.org/10.1186/s41476-020-00140-9

Following publication of the original article [1], we have been informed that on Page 9, the circular chord equation (equ 3) is given. Under the root sign we have the term: $2 \mathrm{rh}-\mathrm{r}^{\wedge} 2$ but it should be: $2 \mathrm{rh}-\mathrm{h}^{\wedge} 2$.

The original article has been corrected.

\section{Author details}

'Center for Optical Technologies, Aalen University of Applied Sciences, 73430

Aalen, Germany. ${ }^{2}$ Technical University Deggendorf, Institute for Precision

Manufacturing and High-Frequency Technology, 94244 Teisnach, Germany.

Published online: 20 August 2020

\section{Reference}

1. Pohl, et al.: Mid-spatial frequency error generation mechanisms and

prevention strategies for the grinding process. J. Eur. Opt. Soc.-Rapid Publ.

16, 19 (2020) https://doi.org/10.1186/s41476-020-00140-9

\footnotetext{
The original article can be found online at https://doi.org/10.1186/s41476020-00140-9.

* Correspondence: mario.pohl@hs-aalen.de

The original article can be found online at https://doi.org/10.1186/s41476-

020-00140-9

${ }^{1}$ Center for Optical Technologies, Aalen University of Applied Sciences, 73430

Aalen, Germany

Full list of author information is available at the end of the article
}

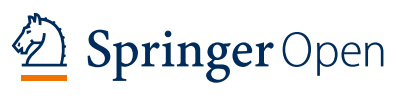

( ) The Author(s). 2020 Open Access This article is licensed under a Creative Commons Attribution 4.0 International License, which permits use, sharing, adaptation, distribution and reproduction in any medium or format, as long as you give appropriate credit to the original author(s) and the source, provide a link to the Creative Commons licence, and indicate if changes were made. The images or other third party material in this article are included in the article's Creative Commons licence, unless indicated otherwise in a credit line to the material. If material is not included in the article's Creative Commons licence and your intended use is not permitted by statutory regulation or exceeds the permitted use, you will need to obtain permission directly from the copyright holder. To view a copy of this licence, visit http://creativecommons.org/licenses/by/4.0/. 